\title{
Commentary: The bigger the better, in everything
}

\author{
Michele Di Mauro, MD, PhD, MSc, ${ }^{\mathrm{a}}$ Antonio Calafiore, MD, ${ }^{\mathrm{b}}$ Luigi Leonzio, $\mathrm{MD},{ }^{\mathrm{c}}$ and \\ Alessandro Parolari, $\mathrm{MD}^{\mathrm{c}}$
}

From the ${ }^{a}$ Department of Heart Disease, SS Annunziata Hospital, Chieti; ${ }^{b}$ Department of Cardiac Surgery, Pope John Paul II Foundation, Campobasso; and ${ }^{\mathrm{c}}$ UOC Cardiac Surgery and Translational Research, IRCCS San Donato and University of Milan, San Donato Milanese, Italy.

Disclosures: Authors have nothing to disclose with regard to commercial support.

Received for publication Sept 28, 2019; revisions received Sept 28, 2019; accepted for publication Sept 29, 2019; available ahead of print Oct 24, 2019.

Address for reprints: Michele Di Mauro, MD, PhD, MSc Biostat, Heart Disease Department, SS Annunziata Hospital, Via dei Vestini, 66100, Chieti, Italy (E-mail: mdimauro1973@gmail.com).

J Thorac Cardiovasc Surg 2020;160:922-3

$0022-5223 / \$ 36.00$

Copyright (C) 2019 by The American Association for Thoracic Surgery

https://doi.org/10.1016/j.jtcvs.2019.09.171

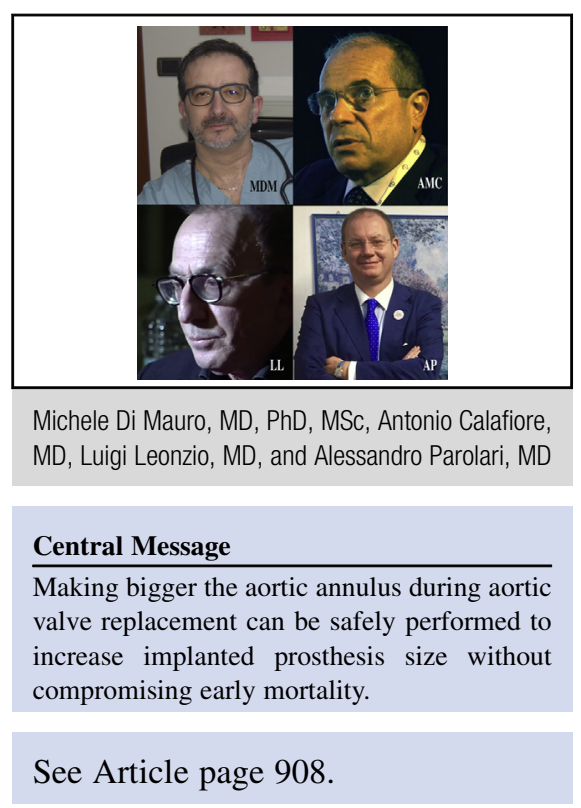

Actually, I do not know if, as stated by Freddie Mercury, the famous frontman of the rock band Queen, "The bigger, the better, in everything," but the study by Derrick Tam and the Toronto University Group ${ }^{1}$ clearly shows that making the aortic annulus bigger during aortic valve replacement (AVR + ANE) can be safely performed to increase implanted prosthesis size without compromising early mortality.

Although root enlargement allows the implantation of a prosthesis even 2 sizes larger, it's still not widely adopted by cardiac surgeons because it's more technically demanding, with possibly greater early mortality and morbidity, especially in terms of bleeding and pacemaker implantation. However, this behavior is supported only by small cohort studies. Hence, one of the strengths of the present study is to demonstrate an equivalent safety either with simple AVR than with AVR and aortic root enlargement (AVR + ANE) in a large cohort of patients (809 in each group), where early mortality is low and similar between the 2 approaches $(2.0 \%$ vs $2.1 \%, P=1.00)$, rate of new pacemaker $(4.8 \%$ vs $6.7 \%, P=.135)$, and any blood product transfusion rate $(66.7 \%$ vs $63.0 \%, P=.131)$. Even late outcome seems to not show any difference, although the final cut of the curve was at 8 years, too early to formulate any conclusions.

We know that nowadays, for the treatment of aortic valve stenosis, bioprosthesis is the first choice in roughly $80 \%$ of patients, ${ }^{2}$ whose Achilles' heel remains anticipated structural valve deterioration, which can be accelerated by patient-prosthesis mismatch. ${ }^{3}$

In the report by Tan and colleagues, ${ }^{1}$ the average body surface area was $1.92 \mathrm{~m}^{2}$, which equates to a mediumhigh body surface but, as we routinely see in the operating theater, this does not necessary mean a great aortic valve root or annulus. In this group of patients, the likelihood of developing moderate or severe patient-prosthesis mismatch $\left(\leq 0.65 \mathrm{~cm}^{2} / \mathrm{m}^{2}\right)$ was higher with reduced late survival, as demonstrated in a meta-analysis of 34 observational studies with more than 27,000 patients. ${ }^{4}$

Heart surgery cannot be reduced to a simple matter of survival. The surgeon also has to assure a good quality of life for patients and, thinking long term, a further lessinvasive approach in case of during aortic valve deterioration.

With the advent of transcatheter aortic valve replacement (TAVR), failing prosthetic aortic valves are often replaced percutaneously with a valve-in-valve (VIV) approach. Today, it is clear that the increasing use of VIV TAVR for failing bioprosthetic valves shows a worse outcome after VIV TAVR in patients with small-sized bioprosthesis; this has renewed the interest of the surgical community in AVR + ANE. . $^{5-7}$

However, a final question is still a doubt still remains in the spotlight of disputes: aortic root enlargement of suture-

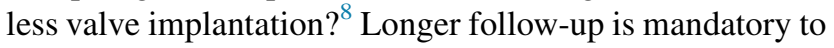
provide a certain response to this question.

The famous Italian novelist Manzoni wrote Ai posteri l'ardua sentenza: Posterity the arduous verdict will declare. ${ }^{9}$

\section{References}

1. Tam DY, Dharma C, Rocha RV, Ouzounian M, Wijeysundera HC, Austin PC, et al. Early and late outcomes following aortic root enlargement: a multi-centered propensity matched cohort analysis. J Thorac Cardiovasc Surg. 2020;160: 908-19.e15. 
2. Rocha RV, Manlhiot C, Feindel CM, Yau TM, Mueller B, David TE, et al. Surgical enlargement of the aortic root does not increase the operative risk of aortic valve replacement. Circulation. 2018;137:1585-94.

3. Flameng W, Herregods MC, Vercalsteren M, Herijgers P, Bogaerts K, Meuris B. Prosthesis-patient mismatch predicts structural valve degeneration in bioprosthetic heart valves. Circulation. 2010;121:2123-9.

4. Head SJ, Mokhles MM, Osnabrugge RL, Pibarot P, Mack MJ, Takkenberg JJ, et al. The impact of prosthesis-patient mismatch on long-term survival after aortic valve replacement: a systematic review and meta-analysis of 34 observational studies comprising 27186 patients with 133141 patient-years. Eur Heart J. 2012;33:1518-29.

5. Dvir D, Webb JG, Bleiziffer S, Pasic M, Waksman R, Kodali S, et al; Valve-inValve International Data Registry Investigators. Transcatheter aortic valve implantation in failed bioprosthetic surgical valves. JAMA. 2014;312:162-70.
6. Webb JG, Mack MJ, White JM, Dvir D, Blanke P, Herrmann HC, et al Transcatheter aortic valve implantation within degenerated aortic surgical bioprostheses: PARTNER 2 valve- in-valve registry. J Am Coll Cardiol. 2017;69: 2253-62.

7. Herrmann HC, Daneshvar SA, Fonarow GC, Stebbins A, Vemulapalli S, Desai ND, et al. Prosthesis-patient mismatch in patients undergoing transcatheter aortic valve replacement: from the STS/ACC TVT registry. J Am Coll Cardiol. 2018;72:2701-11.

8. Dedeilias P, Baikoussis NG, Prappa E, Asvestas D, Argiriou M, Charitos C. Aortic valve replacement in elderly with small aortic root and low body surface area; the Perceval S valve and its impact in effective orifice area. J Cardiothorac Surg. 2016;11:54.

9. Manzoni A. "The Fifth of May" Ode. First reported in ms. VS. X. 3, 1821. 